\title{
Quantifying the impact of land-use changes at the event and seasonal time scale using a process-oriented catchment model
}

\author{
Bettina Ott ${ }^{1}$ and Stefan Uhlenbrook ${ }^{2}$ \\ ${ }^{1}$ Bayerisches Landesamt für Wasserwirtschaft, Wasserwirtschaftsamt Bamberg, Kasernstraße 4, 96047 Bamberg, Germany \\ ${ }^{2}$ University of Freiburg, Institute of Hydrology, Fahnenbergplatz, D-79098 Freiburg, Germany \\ E-mail for corresponding author: stefan.uhlenbro@hydrology.uni-freiburg.de
}

\begin{abstract}
For optimal protection and integrated management of water resources, it is essential to quantify the impact of land-use change on hydrological regimes at various scales. Using the process-based catchment model TAC (tracer aided catchment model, distributed) two land-use scenarios were analysed for the rural and mountainous Dreisam basin $\left(258 \mathrm{~km}^{2}\right)$ : (i) an increase in urban area from $2.5 \%$ to $5 \%$ ) and (2) a change in a natural land-use to a different kind of forest. The first scenario was executed using the land-use change modelling kit LUCK, which takes into account the topology of land-use patterns in their true positions. The $\mathrm{TAC}^{\mathrm{D}}$ model simulated all hydrological processes both spatially and temporally $(200 \mathrm{~m} \times 200 \mathrm{~m}$ grid, hourly mode). For this study, physically-based modules for interception and evapotranspiration (Penman and Monteith approach) were introduced. The model was applied to the Dreisam basin with minimal calibration. Both an independent validation period and discharge in four nested sub-basins were modelled well without recalibration. Evapotranspiration patterns were simulated, successfully, both temporally and spatially. Increased urbanisation had an insignificant effect on the modelled single events and on the yearly water balance. Simulations of discharge from forest assuming natural land-use conditions indicated an increase in transpiration, a decrease in groundwater recharge and, consequently, in groundwater discharge $(-15 \%)$, in surface water discharge $(-4 \%)$, and in flood peaks $(-22.7 \%$ and $-7.3 \%$ for convective and advective floods, respectively). Land-use impact was also investigated by applying rainfall scenarios of different durations (12, 24, 48, and 72 hours), magnitudes (recurrence intervals of 1, 5, and 10 years) and distributions of rainfall intensity, i.e. maximum intensity at the beginning, middle or end of the event. Clearly, the intensity distribution has a greater influence on the simulated events than different land use scenarios. This indicated the importance of careful determination of the temporal intensity distribution for flood peak predictions. The use of the process-based model enabled analysis of the altered composition of internal runoff components. This demonstrated the potentially significant local effects of land-use change on flood runoff and water quality.
\end{abstract}

Keywords: land-use change, predictions, process-based catchment modelling, flood modelling, evapotranspiration modelling, TAC $\mathrm{C}^{\mathrm{D}}$ model, LUCK

\section{Introduction}

Predicting the effects of land-use and climate change on the hydrological cycle is a major challenge for current and future hydrological research (Sivapalan et al., 2003). Although hydrological processes dominate only part of the atmosphere-ocean-land surface system, they are important because global and local changes can affect hydrological processes and vice versa (Beven, 2001). Today, the most important goals of catchment modelling are to quantify and predict the effects of global change at the catchment scale, particularly for future water resources development and extreme events. However, gaps in knowledge of hydrological processes, natural variability in space and time, as well as the complexity and uncertainty of future climate changes, make it difficult to predict the consequences. Previously validated distributed hydrological models incorporating process-based descriptions of all dominating processes may well be the best tools to estimate the impact of such changes (Abbott and Refsgaard, 1996; Beven, 2001). Land-use and climate change impact studies have recently been made at different scales. Both physically-based and conceptual hydrological models have been applied to assess influences on catchment water balances. Fohrer et al. (2001) applied the physically-based hydrological model SWAT ${ }_{\text {mod }}$ to a meso-scale catchment to assess the effect of land-use changes on annual water balances and on temporal runoff dynamics and showed that surface runoff was most susceptible to land-use changes. Two applications of land- 
use change using the ArcEGMO model (Lahmer et al., 2001; Klöcking and Haberlandt, 2002) to meso- and macro-scale catchments demonstrated relatively minor effects on various water balance components but larger effects on water availability. In a semi-humid meso-scale catchment in eastern Germany, Wegehenkel (2002) assessed the impact of afforestation on the water balance using the conceptual hydrological model THESEUS and found a significant reduction in discharge and an increase in evapotranspiration. In each of these studies, the temporal resolution of the models was set to daily time steps and the focus was mainly on long term changes in the water balance. In an eventbased and widely process-oriented modelling approach, a modified version of the physically-based WaSIM-ETH model was applied to a meso-scale catchment (Niehoff et al., 2002); the influence of convective versus advective rainfall events and their distinct influence on storm runoff generation for different land-use conditions was demonstrated clearly.

Recently, many experimental and modelling studies have taken place in the mountainous Dreisam basin $\left(258 \mathrm{~km}^{2}\right)$ and, in particular, in the sub-basin Brugga $\left(40 \mathrm{~km}^{2}\right)$. Various catchment models, TOPMODEL (Güntner et al., 1999), HBV (Uhlenbrook et al., 1999), PRMS/MMS (Mehlhorn, 1999) and NPSM (Eisele et al., 2001) were applied. However, intensive testing of the models with different experimental data showed that the model structures were inadequate for this basin; the model runoff generation processes and runoff components disagreed with the experimental findings of particular tracer studies. This led to the development of the semi-distributed TAC model (tracer aided catchment model; Uhlenbrook and Leibundgut, 2002), which simulated internal flow dynamics correctly (as far as could be proven). A further development of the model, the TAC ${ }^{\mathrm{D}}$ (TAC, distributed), is a fully distributed model able to simulate water fluxes at a detailed temporal and spatial resolution $\left(50 \times 50 \mathrm{~m}^{2}\right.$, hourly time step; Uhlenbrook et al., 2004). It also includes a runoff routing module to simulate floods. The interception of rain was modelled relatively simply and evapotranspiration was calculated using the Turc-Wendling approach, which accounts for the topographic influence on potential radiation but does not consider various vegetation parameters.

The objectives of this study were, firstly, to test the suitability of a modified version of the $\mathrm{TAC}^{\mathrm{D}}$ model for predicting the impact of land use change. Thus, this processoriented and distributed model with a detailed runoff generation module had to be extended to simulate surface processes (interception and evapotranspiration) in a physically-based and spatio-temporally detailed way. Secondly, the influences of two land-use scenarios in the rural Dreisam basin were compared with present-day conditions: (i) a $100 \%$ increase (from $2.5 \%$ to $5 \%$ ) in the area of settlements and (ii) natural land use. Therefore, the water balance components, flood peaks and the composition of runoff components were examined. Thirdly, the impact of land-use change on floods during different conditions was analysed by differentiating between convective and advective rain events as well as for floods of different magnitudes (recurrence intervals of 1,5 , and 10 years) caused by different rainfall durations $(12,24,48$, and 72 hours) and rainfall intensity distributions.

\section{The Dreisam basin and dominant hydrological processes}

The study was made in the meso-scale Dreisam basin $\left(258 \mathrm{~km}^{2}\right.$; Fig. 1) and the Brugga $\left(40 \mathrm{~km}^{2}\right)$, St. Wilhelmer Talbach $\left(15.2 \mathrm{~km}^{2}\right)$, Zastler $\left(18.4 \mathrm{~km}^{2}\right)$ and Rotbach $(42.3$ $\mathrm{km}^{2}$ ) sub-basins located in the southern Black Forest Mountains in south-west Germany. The basin is mountainous with elevations ranging from 309 to $1493 \mathrm{~m}$ a.s.l. and a nival runoff regime (Table 1). The bedrock consists of gneiss and different metamorphic rocks, covered by soils and drift $0-10 \mathrm{~m}$ deep. In the drift material, which is of glacial and periglacial origin, brown soils have developed. In the periglacial drift, solifluction processes caused layers with lower and higher hydraulic conductivities, which enhance interflow processes. The permeability of the top soils is generally high with $K_{\text {sat }}$-values $>10^{-4} \mathrm{~m} \mathrm{~s}^{-1}$. The infiltration capacity is too high to generate infiltration excess except in some urban areas. Water saturated areas, which are dominated by saturated overland flow, cover about $1.6 \%$ of the catchment and for the most part are connected directly to the river system.

The mean annual precipitation is approximately $1500 \mathrm{~mm}$, generating a mean annual surface discharge of approximately $820 \mathrm{~mm}$ and a groundwater outflow of $60 \mathrm{~mm}$. The mean annual actual evapotranspiration is about $600 \mathrm{~mm}$. About $20 \mathrm{~mm}$ is abstracted from groundwater to supply water to the city of Freiburg, near the Dreisam basin outlet. Precipitation varies significantly with elevation. Mean annual precipitation near the top of the Feldberg mountain ( $1480 \mathrm{~m}$ a.s.1.) is $1900 \mathrm{~mm}$, while near the outlet in Freiburg (269 m a.s.l.) the average is only $955 \mathrm{~mm}$ (Fuchs et al., 2001). Elevation gradients of temperature are also observed; the mean temperature at Feldberg is $3.2^{\circ} \mathrm{C}$ and at Freiburg, $10^{\circ} \mathrm{C}$ (Trenkle and Rudloff, 1989). About two-thirds of the precipitation falls as snow at the Feldberg and a $30 \mathrm{~cm}$ snow cover is continuous for about 60 days per year in the upper parts of the basin (Ries, 1992) but only for a few days in the main valley of the Dreisam. 


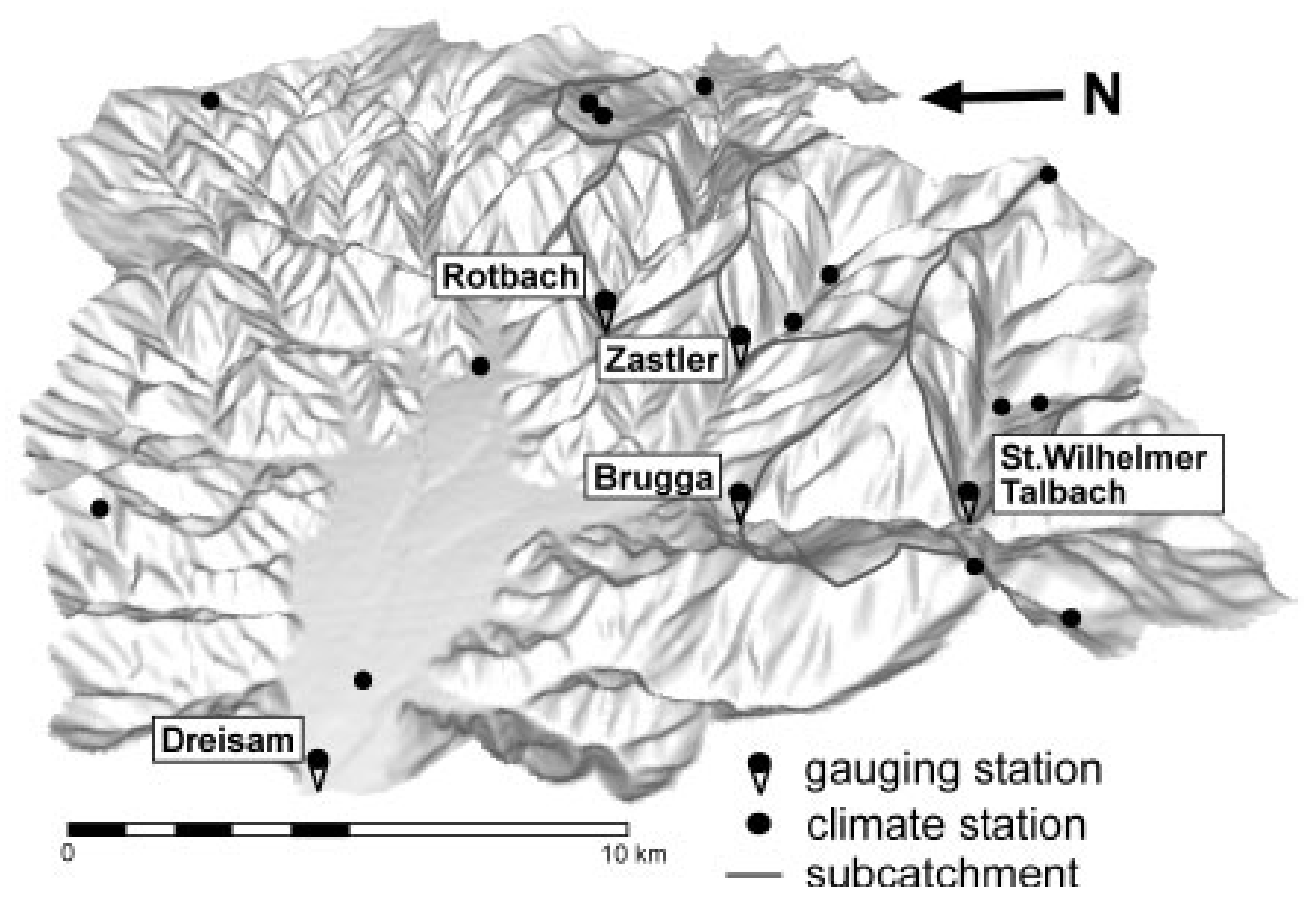

Fig. 1. 3-dimensional sketch of the mountainous Dreisam basin (Black Forest, south-west Germany), differently sized sub-basins and instrumentation network.

Table 1. Main physiographic characteristics of the Dreisam basin

\begin{tabular}{|c|c|c|c|c|c|}
\hline Land use classes & {$[\%]$} & Runoff generation units & {$[\%]$} & Slope classes & {$[\%]$} \\
\hline Urban area & 2.6 & (1) Horton overland flow & 3.0 & $0-10^{\circ}$ & 43.6 \\
\hline Arable farm land & 4.3 & (2) Saturation overland flow & 1.6 & $10-20^{\circ}$ & 41.8 \\
\hline Pasture land & 21.6 & (3) Fast sub-surface storm flow & 13.6 & $20-30^{\circ}$ & 12.9 \\
\hline Fallow land & 7.5 & (4) Fast sub-surface storm flow, piston flow & 7.6 & $30-40^{\circ}$ & 1.7 \\
\hline Forest & 63.4 & (5) Delayed interflow & 54.3 & & \\
\hline Rocks & 0.5 & (6) Very delayed interflow & 5.3 & & \\
\hline \multirow[t]{2}{*}{ Surface water } & 0.1 & (7) Deep percolation & 7.7 & & \\
\hline & & (8) Large porous groundwater & 6.9 & & \\
\hline
\end{tabular}

Two main topographic areas can be distinguished (Fig. 1, Table 1). The main valley ('Zartener Becken') from the centre of the basin to the outlet is the flatter part of the area (about 8\% slope) and a large porous aquifer (up to $50 \mathrm{~m}$ deep), used for water supply is underneath. Land use is farm and pasture land and urban settlements (Fig. 4). The mountainous part of the basin is characterised by steep hill slopes, bedrock outcrops, deeply-incised and narrow valleys and gentler areas at the mountaintops (Fig. 1). Forest is predominant on the hill slopes, while the narrow valley floors and hilly upper parts of the basin are pasture. Urban land use is less than $2 \%$ in the mountainous part of the Dreisam basin.
In recent years, experimental investigations using artificial and naturally occurring tracers have been undertaken to identify runoff sources and flow pathways, quantify runoff components and date the different water compartments (Uhlenbrook et al., 2002); surface runoff was generated only on impermeable or saturated areas and on steep highly permeable slopes covered by boulder fields. Sub-surface storm flow components can also be generated on hill slopes with permeable soil and periglacial drift material, situated above the almost impermeable bedrock, or at the lowpermeability drift cover layers. Base flow components originate from the fractured hard rock aquifer and the deeper parts of the weathering zone. 


\section{Model description}

\section{STRUCTURE OF THE MODEL TAC ${ }^{D}$}

An extended version of the $\mathrm{TAC}^{\mathrm{D}}$ (tracer aided $\underline{\text { catchment }}$ model, distributed) model was used in this study. A brief summary of the model (Uhlenbrook et al., 2004) is provided here; in particular, new model components are described in further detail.

$\mathrm{TAC}^{\mathrm{D}}$ is a process-oriented catchment model with a modular structure. It can be applied in short time steps (5min steps were the shortest so far) and is fully distributed, using grid cells as spatial discretisation. In this study, the cell size was set to $200 \times 200 \mathrm{~m}^{2}$ for computational reasons. The water is routed between the cells by applying the singleflow direction algorithm (D8), which is suitable for a mountainous test site where water flow direction is dominated by the steepest gradient. It is coded within the GIS PC-Raster (Karssenberg et al., 2001) that offers a dynamic modelling language. Some modules were adapted from the literature and modified for the specific circumstances at the test site. The core of the process-based model is the runoff generation module working in combination with a spatial delineation of hydrological functional units.

\section{MODEL INPUT: METEOROLOGICAL DATA}

Precipitation $\left[\mathrm{mm} \mathrm{h}^{-1}\right.$ ] was observed at up to 15 stations in or near the Dreisam catchment (Fig. 1, Table 2). Five stations collected data either hourly or more frequently; ten stations taking three measurements a day or daily values were disaggregated to hourly resolution by transferring the temporal pattern of the closest station. The systematic measurement error caused by wind was corrected using an approach of Schulla (1997), and the undercatch of solid precipitation was corrected in the snow module. An inverse distance weighting method (80\%) and an elevation gradient method $(20 \%)$ were used to regionalise precipitation to catchment scale. For the latter, a temporally constant elevation factor, estimated using a non-linear regression function between station height and mean precipitation, was applied. This was used because, although the elevation dependence of precipitation was observed for longer time periods (monthly, yearly), it could not always be observed in hourly time steps. Thus, the location of rain cells is more important than elevation during specific storm events. The regionalisation scheme is a compromise between capturing the spatial distribution on the event scale and reproducing the long-term pattern.

Global radiation $\left[\mathrm{Wh} \cdot \mathrm{m}^{-2}\right.$ ] was calculated using the model POTRAD(2003) developed for GIS PC-Raster (Dam, 2000). This model calculates the incoming global radiation as flux for a given time step and grid cell, accounting for topography (slope, aspect and shadowing effects), solar geometry (declination of the sun, latitude and azimuth angle) and sunshine duration (cloudiness). The model output was compared, successfully, to measured radiation at two locations for specific periods.

Temperature $\left[{ }^{\circ} \mathrm{C}\right]$ was observed at ten locations and regionalised by combining an elevation gradient with a

Table 2. Parameter values for soil and river network characteristics used in the calibration and the scenario 'natural conditions' for different hydrological function units (see text).

\begin{tabular}{llcc}
\hline Parameter & Unit & Calibration & Scenario 'natural conditions' \\
\hline FC_3 & $\mathrm{mm}$ & 90 & 90 \\
$F C \_4$ & $\mathrm{~mm}$ & 200 & 220 \\
$F C \_5$ & $\mathrm{~mm}$ & 130 & 143 \\
FC_6 & $\mathrm{mm}$ & 200 & 220 \\
FC_7 & $\mathrm{mm}$ & 250 & 290 \\
FC_8 & $\mathrm{mm}$ & 220 & 264 \\
BETA_3 & - & 1.25 & 1.25 \\
BETA_4 & - & 1.5 & 1.35 \\
BETA_5 & - & 1.5 & 1.35 \\
BETA_6 & - & 1.5 & 1.35 \\
BETA_7 & - & 1.8 & 1.5 \\
BETA_8 & - & 1.75 & 1.4 \\
Riverlength per cell & $\mathrm{m}$ & 208.5 & 229.35 \\
Manning's $n$ & & & \\
(local drainage area $\left.>50 \mathrm{~km}^{2}\right)$ & - & 0.04 & 0.06 \\
\hline
\end{tabular}


topography modification. Different elevation gradients were used for the upper and lower parts of the catchment; these were derived by linear regression from hourly observations at five stations below and above $750 \mathrm{~m}$ a.s.1. Thus, temperature increases with elevation (inversion), frequently found at the higher elevations during high-pressure periods in winter, were taken into account. The estimated temperature for each time step and grid cell was modified due to the influence of topography and solar geometry as for the calculation of the global radiation above. Finally, based on sunshine duration, the temperature was modified for every time step.

Wind velocity $\left[\mathrm{m} \mathrm{s}^{-1}\right]$ was aggregated to hourly values at six stations within the catchment for estimating bulkaerodynamic resistance in the evaporation module and for assessing precipitation measurement error. It was transferred to the other stations by using the closest station directly. The sunshine duration [-] was measured hourly at four stations. Humidity [\%], aggregated to hourly values, was measured at nine stations. All three variables were regionalised to catchment scale by applying the inverse distance weighting method.

\section{POTENTIAL EVAPOTRANSPIRATION}

Estimating the impacts of land-use change in the Dreisam basin with its variable topography (slope, aspect, shadowing effects) and physiographic characteristics (soils, vegetation cover, etc.) requires a precise and spatio-temporally variable calculation of evapotranspiration. The potential evapotranspiration was calculated using the physically based Penman-Monteith approach, discussed in Shuttleworth (1993), as it is the state-of-the art method for this catchment scale. This approach incorporates hourly temperature, wind speed, potential radiation, humidity and sunshine duration. The soil heat flux was set to $10 \%$ of the net radiation according to Schulla (1997).

Vegetation parameters required to account for the spatially and temporally variable land-use cover were bulk-surface resistance $\left[\mathrm{s} \cdot \mathrm{m}^{-1}\right]$, albedo $[-]$, leaf area index $\left[\mathrm{m}^{2} \cdot \mathrm{m}^{-2}\right]$, and effective plant height [m]. Parameter values were varied monthly for each land-use class (DVWK, 1996; Schulla, 1997; Bremicker, 2000). Evaporation from snow was taken into account by monthly variable values of $0.01-0.3$ $\mathrm{mm} \cdot \mathrm{d}^{-1}$ (DVWK, 1996). Actual evapotranspiration was computed for each cell depending on continuous soil moisture simulation and on the intercepted water stored on the vegetation. Potential evapotranspiration was reduced linearly if the local soil moisture storage was below $60 \%$ of the maximum soil moisture storage capacity according to Menzel (1997). All the parameters of this module were obtained from the literature or from land-use maps and were not modified during model calibration.

\section{SNOW MODULE}

A snow module based on a temperature index method was used for simulation of snow-cover development (Bergström, 1992). Precipitation is modelled as snow if air temperature at the specific grid cell is below the threshold temperature TT $\left[{ }^{\circ} \mathrm{C}\right]$. This parameter was varied for non-urban $(T T)$ and urban areas $\left(T T_{\text {urban }}\right)$ to account for different snow accumulation conditions because of the higher winter temperatures in urban areas. Snowmelt is initiated if air temperature at the specific grid cell is above the threshold temperature $T T$; soil temperature is not considered. TT was varied for urban, forest, and open areas ( $T T_{\text {melt-urban }}$, $T T_{\text {melt-forest }}$ and $T T_{\text {melt-open }}$ ) to account for different snowmelt conditions. The other parameters in the snow module are $C F M A X\left[\mathrm{~mm} \mathrm{~h}^{-1}{ }^{\circ} \mathrm{C}^{-1}\right]$, which defines the melted water, and $S F C F[-]$, a snowfall correction parameter to account for the systematic error during snowfall measurement; the precipitation at each cell is multiplied by this parameter, which was determined by calibration as 1.08. CFMAX applied to non-urban areas and $C F M A X_{\text {urban }}$ to urban areas to account for different snowmelt conditions in urban areas. Melted water flows to the interception module but can be stored in the snow cover with up to $10 \%$ of the water equivalent. If the air temperature falls below $T T$, the stored melt water can refreeze until it reaches $5 \%$ of the liquid water stored in the snow cover. Both percent values were obtained from Bergström (1992) and were not optimised during the model calibration. All model parameters were determined during the model calibration but ranges of each parameter were pre-defined from the literature and previous applications of the module in this area (Uhlenbrook et al. 1999, 2004).

\section{INTERCEPTION MODULE}

The interception of precipitation can be highly variable in space and time, particularly in catchments with mixed land use, so an interception module based on Dam (2000) was used. It assumes that the amount of precipitation intercepted reaches the maximum interception storage asymptotically (Hoyningen-Huene, 1983; Braden, 1985):

$$
P_{i}=S I_{\max } \cdot\left(1-\frac{1}{1+\frac{C O V \cdot P}{S I_{\max }}}\right)
$$


with $P_{i}\left[\mathrm{mmh}^{-1}\right]$ as intercepted precipitation, $S I_{\max }[\mathrm{mm}]$ as maximum interception capacity, $C O V$ [-] as degree of vegetative covering, and $P\left[\mathrm{mmh}^{-1}\right]$ as precipitation. The maximum interception capacity varies for each land-use category according to the leaf area index and the degree of vegetative covering (Schulla, 1997):

$$
S I_{\max }=C O V \cdot L A I \cdot h_{S I}+(1-C O V) \cdot h_{S I}
$$

with $L A I\left[\mathrm{~m}^{2} \mathrm{~m}^{-2}\right]$ as leaf area index and $h_{S I}[\mathrm{~mm}]$ as maximum height of water on the surface. The intercepted water evaporates directly from the plant surface according to the potential evapotranspiration calculated at each time step. Water that is not evaporated remains as interception storage, $S I$, as long as its maximum, $S I_{\max }$, is not exceeded. If $S I_{\max }$ is exceeded, additional rain or snowmelt water is transferred to the soil module. All parameters of the module were obtained from the literature and from land-use maps; they were not modified during model calibration.

\section{SOIL MODULE}

For all units with a soil zone (i.e. other than those with dominating Hortonian or saturation overland flow), the soil water module from the HBV model (Bergström, 1992) was applied. It has two parameters that were varied for each landscape unit: the maximum amount of water that can evaporate from soil storage, $F C$ [mm], estimated for each raster cell from soil maps and a macro-porosity parameter that describes the water transfer to the runoff generation routine, BETA [-]; this can be determined if soil characteristics are known and different soil types are compared. The module is process-realistic because percolation to the runoff generation routine is possible before field capacity (defined by $F C$ ) is reached. This is calculated based on actual soil moisture measurements using a nonlinear function defined by BETA.

\section{RUNOFF GENERATION MODULE}

Spatial delineation of units with the same dominant runoff generation processes

Based on previous experimental investigations, Tilch et al. (2002) developed an objective approach to delineating units for which similar dominant runoff behaviour can be assumed. Different hydrogeological units, surface characteristics and topography are considered as major controls on runoff processes for each grid cell. The delineation approach is the basis for spatial discretisation of the TAC ${ }^{\mathrm{D}}$ runoff generation routine and differentiates between unit types for the Dreisam basin (Fig. 2, Table 1):
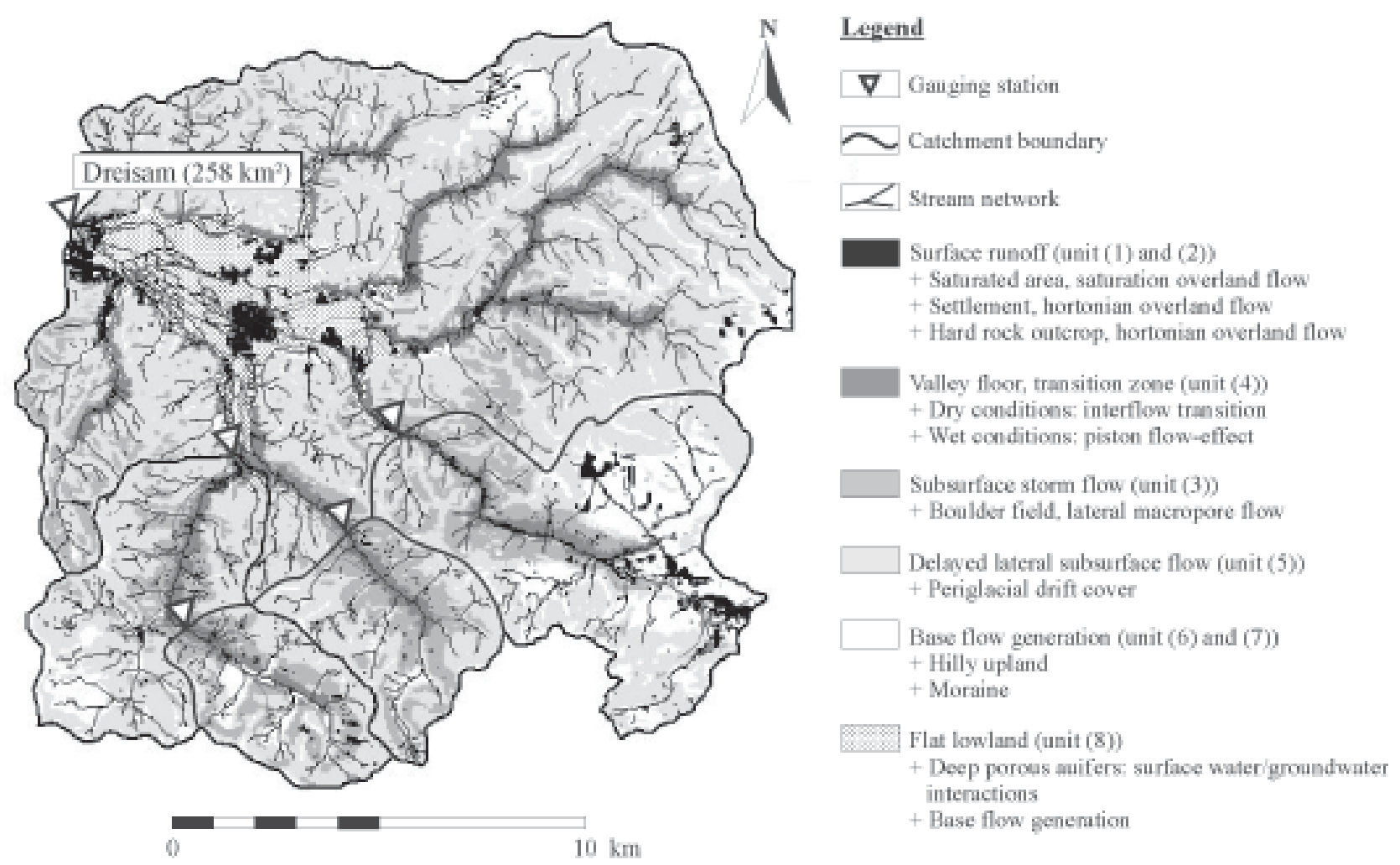

Fig. 2. Landscape units with the same dominant runoff generation processes at Dreisam basin. 
(1) units dominated by Hortonian overland flow (3\% of catchment area), i.e. the impervious part of urban areas and bedrock outcrops;

(2) units dominated by saturation overland flow (1.6\%), i.e. parts of the stream cell that are covered by water bodies, continuously wet areas in the riparian zones, or near springs and mires;

(3) units dominated by fast sub-surface storm flow (13.6\%), i.e. very steep areas (slope greater than $25^{\circ}$ ) with blocks and boulder fields;

(4) units dominated by fast sub-surface storm flow and piston flow (7.6\%), i.e. accumulation and colluvium zones at the toes of hillslopes (slope angle: $0-25^{\circ}$ );

(5) units dominated by delayed interflow (54.3\%), i.e. hillslopes (slope angle: 6-25 $)$ with stratified soils and drift covers (peri-glacial drift), with a base layer (dense, adjusted stones) and a main layer (sandy loam with stones), both covering the weathered bedrock. Lateral flow is dominant in the main layer and perched aquifers can be established;

(6) units dominated by very delayed, damped interflow $(5.3 \%)$, i.e. moraines that are heterogeneous in their structure and grain size distribution;

(7) units in elevated areas dominated by deep percolation $(7.7 \%)$, i.e. flat or hilly areas at the hilltops (slope less than $6^{\circ}$ ) with loamy soils with a relatively deep weathering profile. Water percolates to the deeper parts of the weathering zone and the fractured bedrock and runs off slowly, contributing to base flow;

(8) units with large porous aquifers $(6.9 \%)$, i.e. main valley ("Zartener Becken") with sandy and loamy soils. Infiltrating water percolates to the porous aquifer and contributes to base flow.

The spatial delineation used the original DEM $(50 \mathrm{~km} \times$ $50 \mathrm{~km}$ grid size). Aggregation to the model cell size $(200 \mathrm{~km} \times 200 \mathrm{~km})$ resulted in only minor changes to the proportions of each runoff generation unit (less than $4 \%$ for one unit type).

\section{Modelling of lateral flows}

A reservoir-based approach was used to conceptualise the runoff generation processes within the TAC ${ }^{\mathrm{D}}$ model. Reservoir systems with parallel, sequentially connected, or 'overflowing' reservoirs were designed for each of the eight units, based on knowledge of the dominant runoff generation processes (Fig. 3). The outflow of each linear reservoir $Q$ $\left[\mathrm{mm} \mathrm{h}^{-1}\right]$ depends on the reservoir content $S[\mathrm{~mm}]$, the storage coefficient $k\left[\mathrm{~h}^{-1}\right]$, and the local slope at the respective raster cell:

$$
Q=k_{*} S_{*}(1+\tan b / \tan b(\text { mean }))
$$

with $b\left[^{\circ}\right]$ as the slope at the modelled cell, and $b\left(\right.$ mean) $\left[^{\circ}\right]$ as the mean slope of the runoff generation unit of the modelled cell. The slope term was added to the normal reservoir equation to account for the variable slope within each unit class. Figure 3 shows how the reservoirs were constructed for each unit type described in the previous section, and how the lateral flows were linked.

The proportion of impermeable areas in each urban raster cell was distinguished from the portion of areas where infiltration is still possible (open spaces, gardens, etc.) in simulating the runoff from urbanised areas. The proportion was set to $60 \%$, due to the rural structure of the settlements. For the pervious areas within urban raster cells, the soil and runoff generation routine of the respective runoff unit type was calculated depending on the unit type underlying the settlement. The surface runoff from the sealed area reaches the next cell or the stream if the cell is connected to the stream network, within the same modelling time step. This is suitable for rural study basins that contain only small settlements. For catchments with larger urbanised areas with urban drainage systems, or for shorter modelling time steps, a more detailed routing would be required.

The runoff generation of cells divided by a stream was separated into two parts: $(i)$ precipitation falling on the stream area (stream widths multiplied by mean stream length) was added directly to the stream and transferred with the routing module; (ii) precipitation on the remaining area must pass through the soil and runoff generation routine of the respective unit type. The outflow of these routines goes directly into the stream and is routed accordingly.

All model parameters of this module were determined during model calibration but ranges of each could be predefined from previous applications (Uhlenbrook et al., 2004)

\section{ROUTING MODULE}

The kinematic wave approach with an implicit non-linear approach (Chow et al., 1988) was used to simulate runoff routing in the stream network. For the streams that are divided into sections by the $200 \mathrm{~m} \times 200 \mathrm{~m}$ cell size, a shorter modelling time step had to be used. An adequate temporal resolution for this routine was found to be 360 seconds. The channel network was taken from the DEM. The routing module requires channel slope at each location, also derived from the DEM, assuming that the slope of the energy line equals the slope of the riverbed, which is plausible for the mountainous test site. Where the streamline winds, the mean length of the digitised channel network of $209 \mathrm{~m}$ per channel 


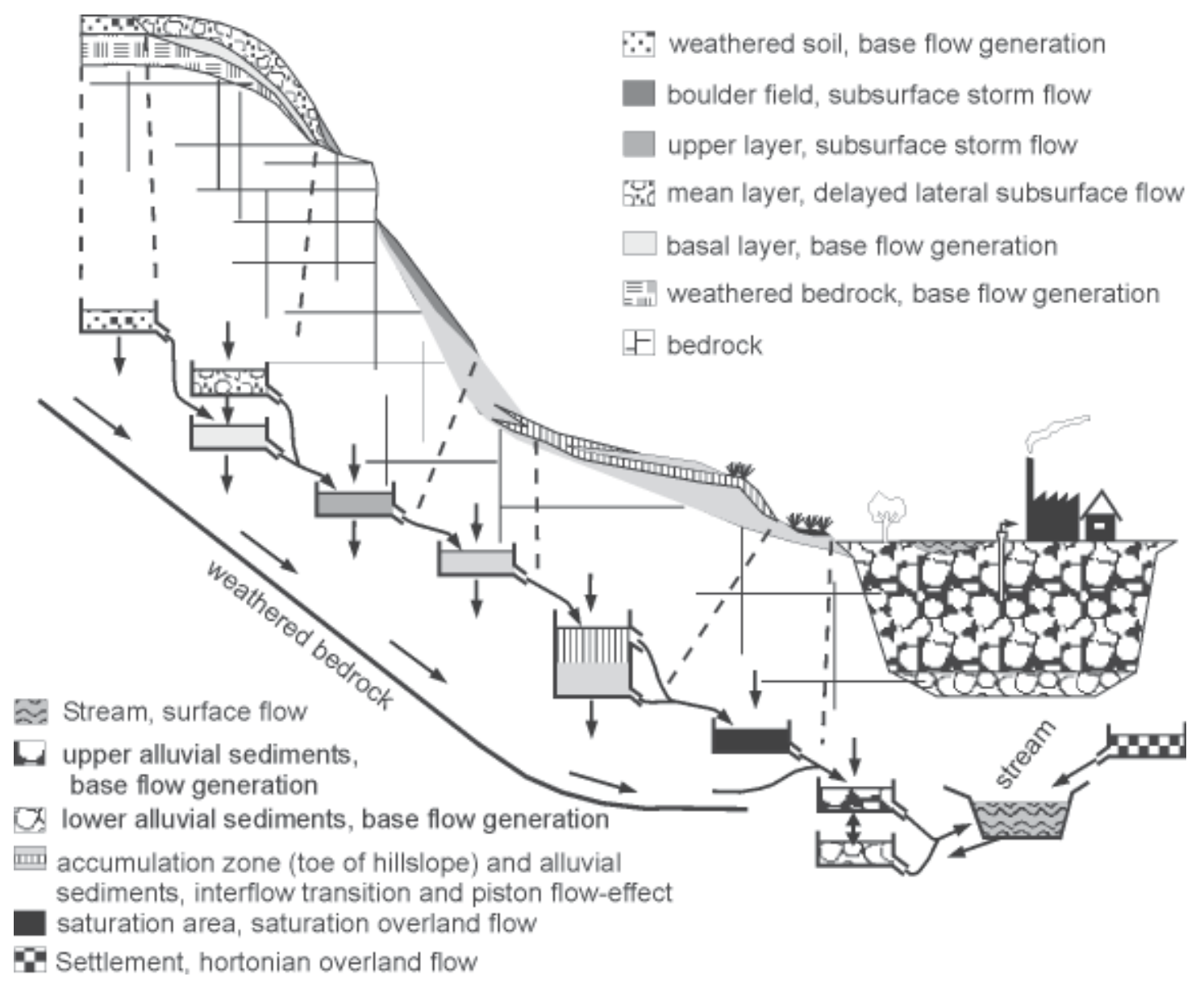

Fig. 3. Schematic sketch of a hill slope and conceptualisation of runoff generation processes by distributed and interlinked reservoirs within the TAC $C^{D}$ model.

cell was used as channel length. Channel widths were estimated empirically $\left(\mathrm{R}^{2}=0.87\right)$, describing the width as a function of the local drainage area; this regression was derived from 67 measurements at different locations within the test site. The roughness coefficients (Manning's $n$ ) were estimated according to Dingman (2002) and set to 0.08 if the local upslope area was less than $5 \mathrm{~km}^{2}$, to 0.06 if the local upslope area was less than $50 \mathrm{~km}^{2}$ and to 0.04 for channel cells with larger upslope areas. All parameters of this module were obtained from the literature and were not modified in calibrating the model.

\section{MODEL SETTINGS, CALIBRATION PROCEDURE AND OBJECTIVE FUNTIONS}

The model was calibrated, in winter (01.11.199530.04.1996) and in spring and summer (22.02.199715.08.1997). An independent period of one year (01.06.1998-31.05.1999) was used for validation (splitsample test as suggested by Klêmes, 1986). The model was initialised over about three months to establish realistic storage volumes at the beginning of each simulation period.

The periods were selected based on the availability of data. The calibration was performed manually to obtain the best agreement between simulated and observed runoff at the Dreisam basin outlet $\left(258 \mathrm{~km}^{2}\right.$; see Figs. 1 and 2). The observed discharges at the sub-basins (i.e. Brugga $40 \mathrm{~km}^{2}$, St. Wilhelmer Talbach $15.2 \mathrm{~km}^{2}$, Zastler $18.4 \mathrm{~km}^{2}$, and Rotbach $42.3 \mathrm{~km}^{2}$; see Figs. 1 and 2) were used only to check the ability of the model to simulate internal variables. At the Zastler gauging station, especially during low flow conditions, the records were unrealistic and seemed to overestimate the discharge systematically. Hence, the calculated objective functions have to be handled with care for this station. Because of the long computation times (about 20 hours for the simulation of one year), few calibration runs (about 70 runs including test runs) were made. An extensive fine-tuning of the model parameters to maximise the objective functions was not undertaken.

The model efficiency, $R_{\text {eff }}(Q)$ [-], (Nash and Sutcliffe, 
1970) and the model efficiency using logarithmic runoff values, $R_{\text {eff }}(\log Q)$ [-], were used to evaluate the agreement between simulated and observed discharge. Values can be between $-\infty$ and $1.0 ; 1.0$ indicates perfect agreement between simulated and observed discharge. In addition, the coefficient of determination, $R^{2}[-]$, was used as a classical statistical measure. To check the water balance simulation, the volume errors, $V E\left[\mathrm{~mm} \mathrm{a}^{-1}\right]$, (observed minus simulated discharge per simulation period) were computed as a fourth objective function.

\section{Land use and rainfall scenarios}

\section{SIMULATION OF LAND-USE CHANGE}

\section{Urbanisation}

An automated tool for land use scenario generation (LUCK, Land-Use Change Scenario Kit; Fritsch, 2002) was used to perform realistic land-use change scenarios that account for the characteristics of each grid cell and its relationships to neighbouring cells. LUCK contains three different modules to simulate changes in urbanisation as well as in agricultural and forest land use. Only the urbanisation module was used in the present study.

LUCK incorporates the topography (DEM), land use, soil characteristics, river network and axes of infrastructural development (main roads, etc.). The spatially averaged, large-scale trend of land-use development must be provided as an external input, the so-called 'scenario target'. The landuse conversion develops gradually using an iterative procedure: Firstly, the site characteristics are evaluated to assess the suitability of conversion from the actual land use to urban land use. Only steep slopes $\left(>10^{\circ}\right)$ and nature conservation areas are excluded. Secondly, the neighbourhood relationships that play a major role in landuse pattern development are analysed. For example, new settlements need to be connected to existing ones. During this iterative procedure, the number of cells already converted is compared constantly to the number set by the scenario target.

An increase in urbanisation from $2.5 \%$ to $5 \%(+100 \%)$ was chosen to assess the influence of land-use change on Dreisam basin hydrology (Fig. 4). 'Present land use' is defined by a detailed map $(30 \mathrm{~m} \times 30 \mathrm{~m})$, based on a LANDSAT TM scene for 1992. For the TAC ${ }^{\mathrm{D}}$ simulations, all model parameters were kept constant except for the landuse map or, possibly, the land-use related parameters at an altered grid cell (albedo, plant height, bulk-surface resistance, LAI and snow melt parameters.)

\section{Natural conditions}

The natural vegetation of the Dreisam basin was chosen as the second land-use scenario. This scenario incorporates the vegetation that would appear naturally according to climate and soils (LfU, 1992). The Dreisam basin would be completely forested with mixed forests (Fagus sylvatica, Picea abies, Abies alba) at higher altitudes and deciduous trees (Fagus sylvativa, Quercus robur) and riparian forest at lower altitudes.

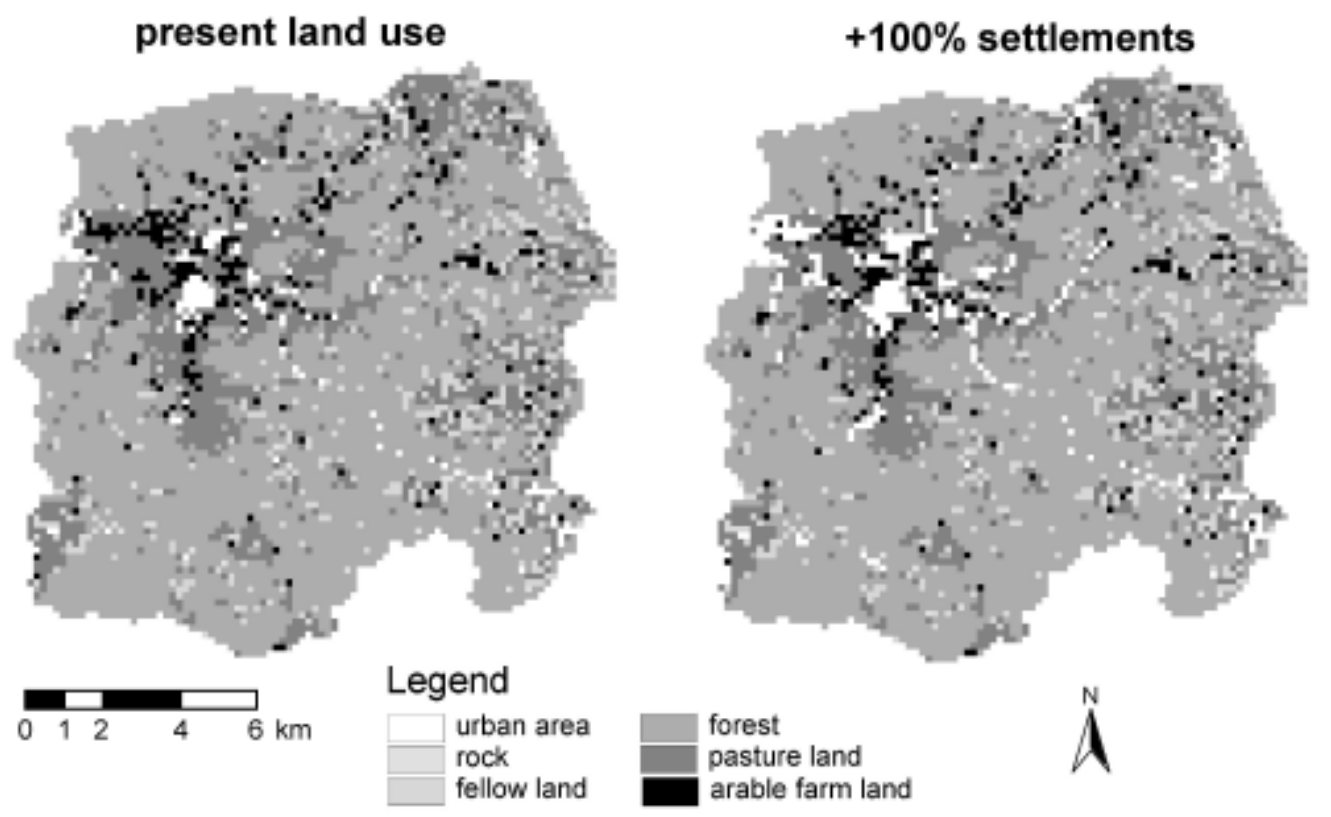

Fig. 4. Present land use and urbanisation scenario (+100\% settlements) of the Dreisam basin. 
Table 3. Results of runoff simulation using $\mathrm{TAC}^{\mathrm{D}}$ in the Dreisam catchment and its sub-basins for the model calibration and validation periods. The values of the Zastlerbach are in brackets, explanation see text.

\begin{tabular}{|c|c|c|c|c|c|}
\hline & Dreisam $258 \mathrm{~km}^{2}$ & Brugga $40 \mathrm{~km}^{2}$ & Rotbach41,1 km² & St. Wilhelm15,2 km² & Zastlerbach $18,4 \mathrm{~km}^{2}$ \\
\hline \multicolumn{6}{|c|}{ CALIBRATION PERIOD (01.11.1995 - 30.04.1996) } \\
\hline$R_{e f f}(Q)$ & 0.819 & 0.921 & 0.585 & 0.791 & $(0.769)$ \\
\hline$R_{e f f}(\log Q)$ & 0.851 & 0.621 & 0.654 & 0.055 & $(-0.452)$ \\
\hline$R^{2}$ & 0.932 & 0.934 & 0.789 & 0.876 & $(0.878)$ \\
\hline$V E[\mathrm{~mm}]$ & -12 & -33 & -18 & -72 & $(-182)$ \\
\hline \multicolumn{6}{|c|}{ CALIBRATION PERIOD (22.02.1997 - 15.08.1997) } \\
\hline$R_{e f f}(Q)$ & 0.874 & 0.656 & 0.491 & 0.699 & $(0.664)$ \\
\hline$R_{e f f}(\log Q)$ & 0.748 & 0.053 & 0.104 & 0.230 & $(-0.024)$ \\
\hline$R^{2}$ & 0.864 & 0.801 & 0.654 & 0.824 & $(0.743)$ \\
\hline$V E[m m]$ & -1 & -14 & 12 & -63 & $(-102)$ \\
\hline \multicolumn{6}{|c|}{ VALIDATION PERIOD(01.06.1998 - 21.05.1999) } \\
\hline$R_{e f f}(Q)$ & 0.779 & 0.549 & 0.687 & 0.797 & $(0.527)$ \\
\hline$R_{e f f}(\log Q)$ & 0.748 & 0.810 & 0.857 & 0.741 & $(0.180)$ \\
\hline$R^{2}$ & 0.884 & 0.608 & 0.788 & 0.807 & $(0.894)$ \\
\hline$V E[m m]$ & -63 & 75 & -84 & 70 & $(-521)$ \\
\hline
\end{tabular}

To consider the natural river network and soil conditions, some parameters were changed by expert knowledge (Table 3 ) to account for a likely increase in soil macro-porosity and storage capacity in natural forest compared to the nonforested actual land use. To exclude the current human influences on the river network in the main valley which is assumed to begin where the local drainage area exceeds $50 \mathrm{~km}^{2}$, the stream length $(+10 \%)$ and the roughness coefficient (Manning's $n$ ) were altered as well. The other model parameters remained unchanged.

\section{RAINFALL SCENARIOS}

To examine catchment response to storm events of different sizes and durations under different land-use scenarios, several rainfall scenarios were applied on an event basis. The amounts of precipitation for different recurrence intervals and storm durations were taken from the German atlas of regionalised rainfall storm events (Bartels, 1997). The precipitation parameters are given for grid cells of approximately $71.5 \mathrm{~km}^{2}$. For seven climate stations within and near the Dreisam basin, the values of the corresponding grid cells were regionalised to catchment scale using the inverse distance weighting method. Recurrence intervals of 1,5 and 10 years were chosen. Analyses of larger recurrence intervals $(50,100$ years, or even longer) were not made, as such large events were not present during the model calibration period. Such calculations would result in uncertain simulations and besides, the impact of land-use change on smaller floods is of particular hydro-ecological relevance.

Dingman (2002) provides a range of typical values of design-storm duration as a function of drainage area. Accordingly, the typical design-storm duration producing the largest peak flood in the Dreisam basin would be between 2 and 20 hours. To analyse the impact of different storm durations, simulations were carried out for four durations: 12, 24, 48 and 72 hours. Shorter durations do not seem feasible, based on historical records of rainfall and discharge. To examine the impact of the temporal rainfall pattern, the simulations were performed for three temporal distributions (Fig. 5): (i) maximum rainfall intensity at the beginning of the event-distribution (1); (ii) maximum rainfall intensity at the end of the event-distribution (2); and (iii) the recommended temporal distribution according to DVWK (1984)-distribution (3). This last distribution has the highest intensity in the middle of the event; $20 \%$ of the precipitation falls in the first $30 \%$ of the event, $50 \%$ in the next $20 \%$ of the event and $30 \%$ during the remainder of the event. Temporally variable rainfall intensity distributions with maxima at the beginning or the end of the event (distributions (1) and (2)) were obtained from DVWK (1984).

One week at the end of the validation period in May 1999 was chosen as the simulation period for the different scenarios. This had the advantage that the model was well initialised after a simulation period of one year. The 


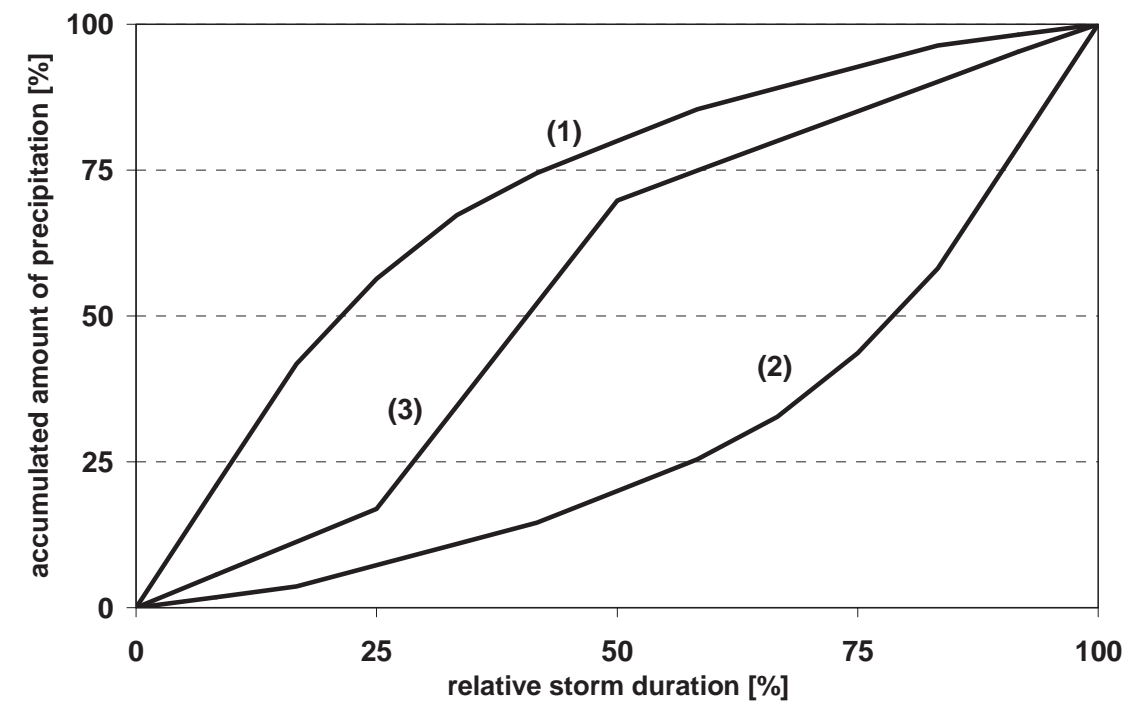

Fig. 5. Different temporal distributions of precipitation during a storm event: (1) maximum intensity at the beginning, (2) maximum intensity at the end, and (3) recommended distribution according to DVWK (1984).

antecedent moisture conditions can be classified as moderate to wet, i.e. the runoff was slightly below the mean flow and all snow had melted about eight weeks previously. The meteorological variables, sunshine duration and humidity had to be estimated to simulate realistic evapotranspiration during the storm events.

\section{Simulation results}

\section{CALIBRATION AND VALIDATION PERIODS}

During the calibration periods good agreement between the simulated and observed discharge for the Dreisam basins and its sub-basins was reached (Fig. 6 and Table 3). The runoff dynamics were reproduced well, with some over- and under-estimations during low and high flow periods. The model encountered difficulties simulating floods generated by rain and snowmelt, as shown for some winter events (Fig. 6a). However, this can be attributed to insufficient input data because of the basin's large altitudinal range and variable snow cover. The intent of the calibration effort was to model the whole period well; thus, the parameters were not optimised explicitly to fit the extremes. The volume error, $V E$, was less than $6 \%$ of the yearly precipitation, except for the uncertain data at the Zastlerbach catchment (Table 4). For most catchments, the agreement was better for the calibration than for the validation period. It is remarkable that the model efficiency, $R_{\text {eff }}(Q)$, was 0.7 for the first model run using parameter values from the literature and from other model applications without any calibration. Although the model was calibrated for the entire Dreisam basin, the results were still good for the sub-basins and, in some cases, were even better than those for the Dreisam.
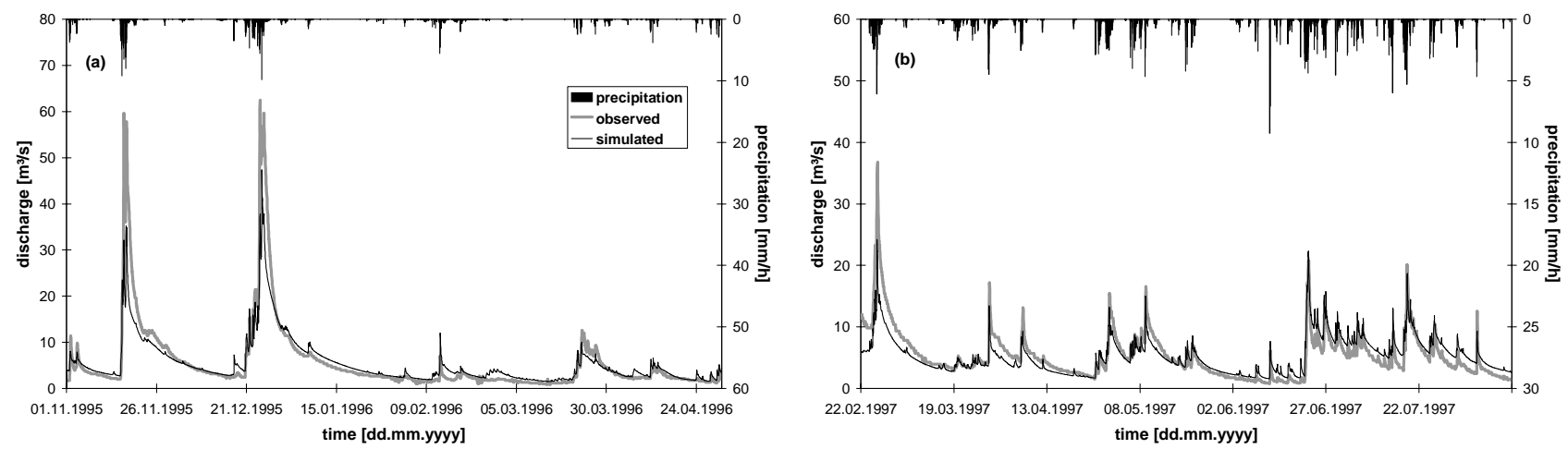

Fig. 6. Results of the discharge simulation in the Dreisam basin using TAC ${ }^{D}$ for the calibration periods ((a) $01.11 .1995-30.04 .1996$ and (b) 22.02.1997-15.08.1997). 
Table 4. Results of simulation of the peak discharge $\left[\mathrm{mm} \mathrm{h}^{-1}\right]$ for different rainfall scenarios (see Fig. 5) applied to the three land use scenarios: (1) present land use, (2) $+100 \%$ settlements, and (3) natural conditions.

\begin{tabular}{|c|c|c|c|c|c|c|c|c|c|c|}
\hline $\begin{array}{l}\text { Rainfall } \\
\text { duration } \\
\text { [h] }\end{array}$ & $\begin{array}{l}\text { Rainfall } \\
\text { intensity } \\
\text { distribution }\end{array}$ & (1) & $\begin{array}{l}1 \\
(2)\end{array}$ & (3) & $\begin{array}{l}\text { Recut } \\
\text { (1) }\end{array}$ & $\begin{array}{l}\text { nce int } \\
5 \\
(2)\end{array}$ & $\begin{array}{l}\text { vall [years] } \\
\text { (3) }\end{array}$ & (1) & $\begin{array}{l}10 \\
(2)\end{array}$ & (3) \\
\hline \multirow[t]{3}{*}{12} & beginning & 32.3 & 34.0 & 29.5 & 48.8 & 51.7 & 43.8 & 53.9 & 57.6 & 48.4 \\
\hline & DVWK & 33.9 & 36.3 & 29.5 & 52.6 & 56.1 & 46.5 & 58.2 & 62.0 & 51.5 \\
\hline & end & 44.0 & 46.3 & 39.8 & 65.5 & 71.2 & 59.9 & 72.5 & 79.4 & 66.4 \\
\hline \multirow[t]{3}{*}{24} & beginning & 36.2 & 38.3 & 33.1 & 50.9 & 53.8 & 46.1 & 53.7 & 56.8 & 48.6 \\
\hline & DVWK & 37.3 & 39.0 & 33.9 & 52.5 & 55.3 & 47.8 & 55.5 & 58.5 & 50.5 \\
\hline & end & 45.7 & 48.5 & 42.0 & 66.1 & 70.0 & 60.2 & 70.1 & 74.6 & 63.7 \\
\hline \multirow[t]{3}{*}{48} & beginning & 32.4 & 33.5 & 29.7 & 45.8 & 47.2 & 42.1 & 53.1 & 54.7 & 49.1 \\
\hline & DVWK & 35.9 & 37.5 & 33.1 & 51.6 & 53.9 & 47.6 & 60.3 & 62.9 & 55.6 \\
\hline & end & 43.3 & 44.9 & 39.8 & 64.1 & 66.3 & 58.7 & 75.2 & 77.7 & 68.9 \\
\hline \multirow[t]{3}{*}{72} & beginning & 33.3 & 34.0 & 30.8 & 49.0 & 50.0 & 45.5 & 54.2 & 55.2 & 50.4 \\
\hline & DVWK & 36.0 & 37.4 & 33.3 & 53.7 & 55.5 & 49.5 & 59.6 & 61.6 & 55.0 \\
\hline & end & 42.6 & 43.9 & 39.3 & 64.8 & 66.5 & 59.7 & 72.3 & 74.1 & 66.8 \\
\hline
\end{tabular}

Simulation of the different evapotranspiration components, i.e. interception, evaporation, and potential and actual evapotranspiration, showed plausible results and the yearly data agree with the results of other studies in this region (Armbruster, 2001). The use of the Penman-Monteith approach was feasible as the required meteorological input, in particular the radiation, could be estimated for every grid cell with the necessary confidence. Other physically-based approaches, as for instance the modified Priestley-Taylor approach, might also give good results in such a mountainous terrain but this approach is very sensitive to the correct estimation of wind speed for each cell. Due to the limited wind data and associated uncertainties with its regionalisation, the Priestley-Taylor approach does not promise better modelling of the evapotranspiration. The influences of variable meteorological conditions, such as increased cloudiness or precipitation, were clearly visible. The seasonal and daily variability were modelled reasonably and the temporal dynamics agreed with the values reported in the literature (DVWK, 1996). A problem for the model evaluation in this, and in comparable studies (Beven, 2001), is the lack of measurements of areal evapotranspiration.

During the one-year validation period, the mean simulated potential evapotranspiration in the Dreisam basin was $686 \mathrm{~mm}$. Of this amount, actual evapotranspiration and evaporation of intercepted water were estimated as $49 \%$ and $28 \%$, respectively. Consequently, total actual evapotranspiration was $528 \mathrm{~mm}$. In the wet upper parts of the catchment, the difference between potential and actual evapotranspiration is very small as soil moisture was limiting only for very short periods in summer. These values are consistent with other evapotranspiration model applications in the Dreisam basin (Kleinhans, 2000; Armbruster, 2001). The power of this physically-based model approach that considers variable topography and land use is demonstrated in the detailed spatially and temporally variable patterns (Fig. 7). The topographic effects expressed by altitude, slope, exposure and shadowing are visible. The higher intensity of incident solar radiation affects the evapotranspiration values at the southerly and westerly exposed hillslopes in the afternoon. In addition, the effect of different land-use types is demonstrated clearly for areas with the same topographic setting but different land use, e.g. hilly uplands in the higher parts of the basins that are used as forest or pasture land.

\section{Urbanisation}

The $100 \%$ increase in urban areas (from $2.5 \%-5 \%$ ) resulted in insignificant changes (maximum of $2 \%$ ) to the annual water balance components (Fig. 8). Two events (dates of peak discharge: 13.08.1995 and 29.10.1998) were analysed in further detail to explore this effect on an event basis. The first event was produced by a convective rainstorm; the second event was a longer, less intense advective rain event. Only minor increases of $+2.5 \%$ and $+0.6 \%$, respectively, in peak discharge were simulated for the convective and advective storm events (Fig. 9). However, the changes in the runoff component 'urban runoff' were significant, with increases of $160 \%$ and $180 \%$. All other runoff components and evapotranspiration losses remained almost unchanged. These negligible influences at the event and seasonal time 

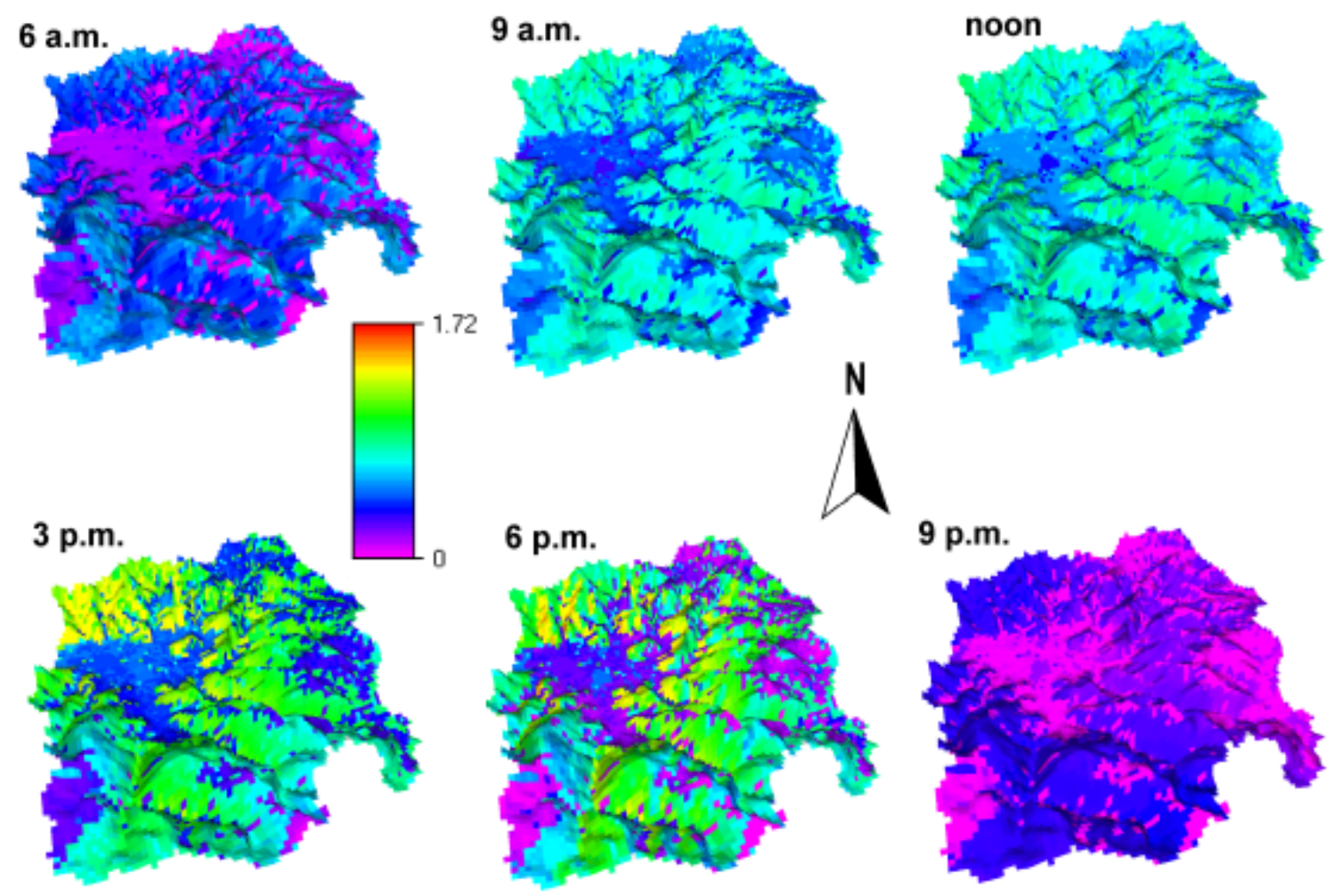

Fig. 7. Spatial and temporal variability of potential evapotranspiration $\left[\mathrm{mmh}^{-1}\right]$ in the Dreisam basin during a summer day (05.08.1995).

scales are due to the small fraction of urban land use in the rural Dreisam basin, so that a $100 \%$ increase resulted in a total urban fraction of only $5 \%$.

\section{Natural conditions}

The scenario for natural conditions with complete tree cover and modified values for soil and river network parameters resulted in significant changes in the simulated water balance as well as in the different runoff components. Annual changes in the water balance components reflect, mainly, changes in the evapotranspiration components (Fig. 8). Increases of $9 \%$ in actual evapotranspiration and of $13 \%$ in evaporation of intercepted water led to a reduction of $4 \%$ in surface water discharge and $15 \%$ in ground water discharge.
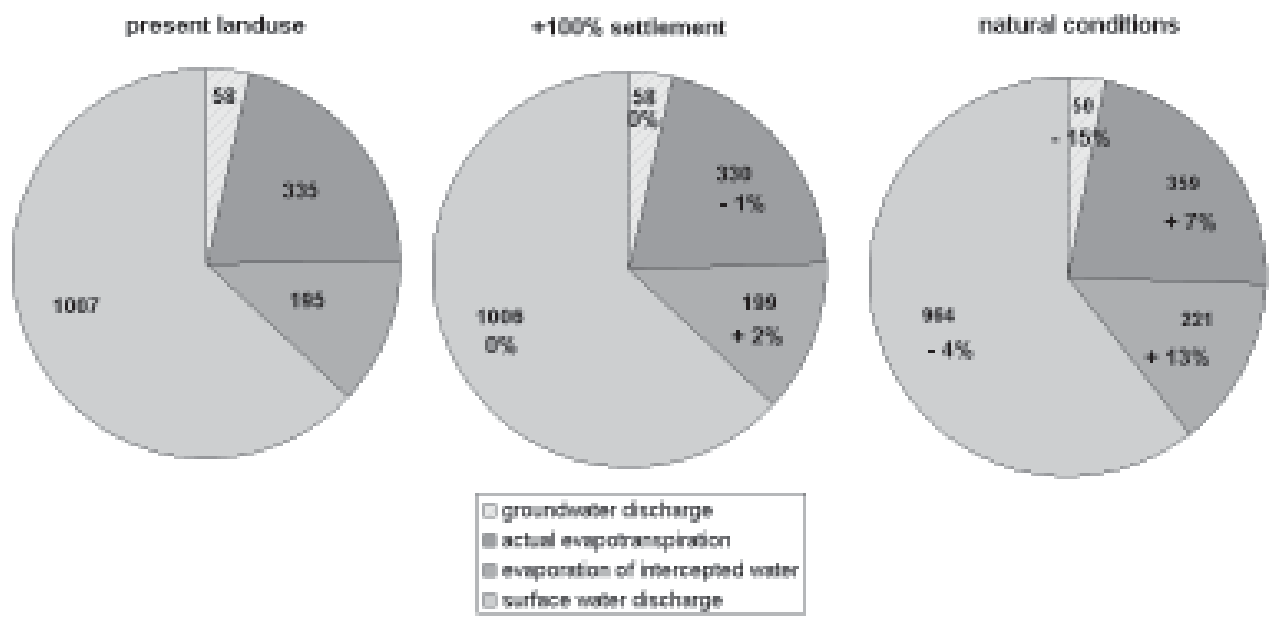

Fig. 8. Water balance components [mma $\left.\mathrm{m}^{-1}\right]$ for the three different land use scenarios and differences compared to present conditions during the validation period (01.06.1998-31.05.1999). 

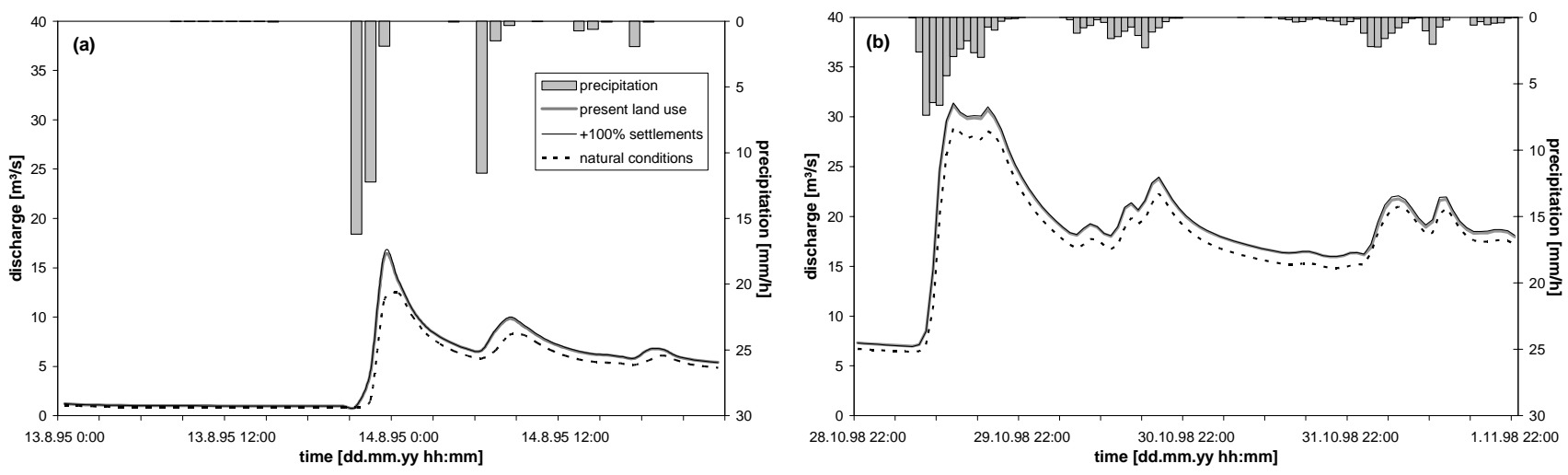

Fig. 9. Simulations of two flood events in the Dreisam basin in response to (a) a convective storm event, and (b) an advective storm event under present and scenario conditions

In addition, soil moisture conditions differed seasonally; in summer, soil moisture was some $10 \%$ lower and, in winter, $10 \%$ higher.

On an event time scale, peak discharges decreased significantly for the advective storm event (-7.3\%) and even more for the convective storm event (-22.7\%) (Fig. 9). In addition, the convective event peak is reached one hour later. An analysis of the contribution of the components of runoff provided insights into the reasons for the changed discharge simulations; the peak reduction in the convective storm event was caused mainly by decreases of $20 \%$ in the 'delayed interflow' and of $26 \%$ in 'fast interflow'. During the advective storm event, in particular, the deep percolation to groundwater in the main valley was $28 \%$ less.

\section{FLOOD SIMULATIONS FOR SEVERAL RAINFALL SCENARIOS}

The different rainfall scenarios have been applied to the three land-use scenarios: present land use, $+100 \%$ urban settlement and natural conditions (Table 4). Figure 10 shows the simulations for the different land-use scenarios for a 48-hour rainfall with a 10 -year recurrence interval. Clearly, the differences caused by the three rainfall intensity distributions are more significant than the differences caused by the three land-use scenarios. However, for all land-use scenarios, the flood peaks increased consistently for the urbanisation scenario and reduced for the natural conditions scenario.

The differences in peak discharge for all rainfall scenarios between the intensity distribution 'DVWK' and the maximum intensity at the end are between $17.5 \%$ and $34.6 \%$; the differences between 'DVWK' and maximum intensity at the beginning are between -13.1 and $-0.2 \%$. In contrast, the changes for the urbanisation scenario are between +4.6 and $+6.1 \%$ and for natural conditions between -9.6 and $-8.1 \%$.

Different rainfall durations generated the highest flood peaks for the respective rainfall intensity distributions (Table 5). For instance, for the simulations with a recurrence interval of one year with maximum rainfall intensity at the end of the event, the largest flood peak is reached for a rainfall duration of 24 hours; for a recurrence interval of five and ten years, rainfall durations of 12 or 48 hours produced the largest flood peaks depending on the land-use scenario. Similar variations could be observed for the other intensity distributions and scenarios for recurrence intervals of five and ten years, but the one-year flood was always highest for the 24-hour rainfall while larger recurrence intervals required longer rainfall durations (48 and 72 hours) to generate the largest flood. The urbanisation scenario was more affected by a shorter rainfall duration (i.e. 12 hours).

\section{Discussion and conclusions}

The process-oriented catchment model $\mathrm{TAC}^{\mathrm{D}}$ is useful for detailed analysis of the influence of land-use change on hydrological regimes in mountainous basins. The integration of a process-based interception module and the incorporation of the Penman-Monteith approach, in combination with a soil routine for simulating evapotranspiration, enabled simulation of the respective processes at a highly detailed spatial and temporal resolution. Therefore, physically based regionalisation of the input data and parameterisation of the vegetation are crucial for a mountainous test site with mixed land use. Spatially more detailed modelling, i.e. finer grid cells than $200 \times 200 \mathrm{~m}^{2}$, is desirable but was not possible in this study for computational reasons. However, the chosen resolution 


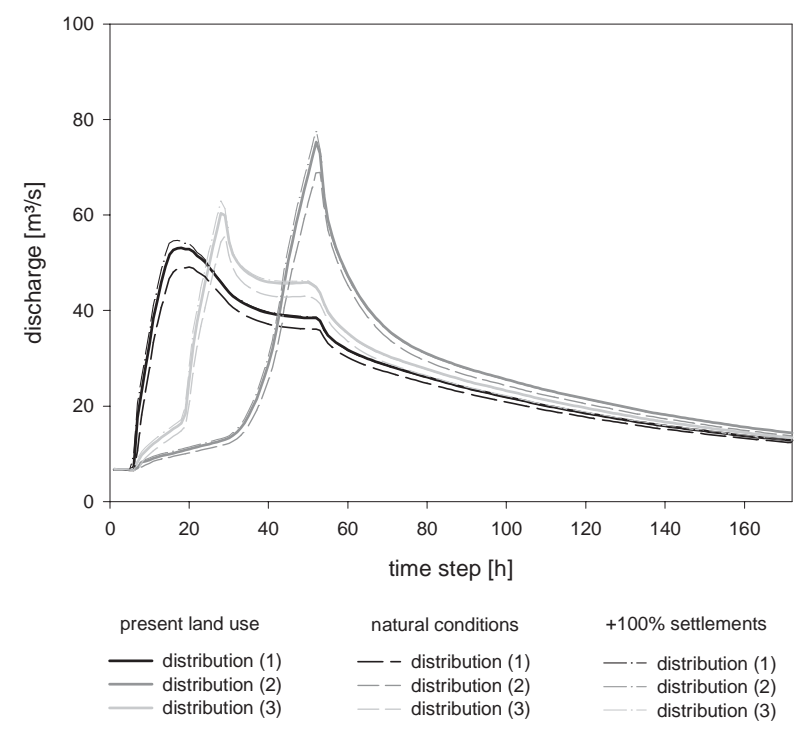

Fig. 10. Simulated hydrographs for three different rainfall intensity distributions (see Fig. 5), for the three different land-use scenarios, for a recurrence interval of 10 years and a rainfall duration of 48 hours.

seems suitable for simulating the impacts of land-use change at the outlet of the meso-scale Dreisam basin, even if modelled micro-scale processes at a specific headwater or channel section were locally insufficient. In addition to greater computational power, more detailed spatial information and local process understanding would be needed to perform reliable predictions at the local scale.

It was possible to identify the influence of land-use change on different water balance compartments from an hourly to a seasonal time scale. A detailed process-oriented model of the runoff generation processes in combination with a routing module, validated previously (Uhlenbrook et al., 2004), were prerequisites to analysing the impact of landuse change on the flood hydrograph. The three-dimensional model structure, in combination with the physically realistic execution of land-use change using the LUCK model, helped to account for the location and lateral interactions of flows between landscape elements for the scenarios modelled. In summary, this model approach has advanced further than comparable daily-resolution studies reported in the literature because the latter are unable to evaluate impacts of landuse change on processes occurring at sub-daily time scales (e.g. spatio-temporal variability of evapotranspiration or flood generation).

The simulations of measured discharge time series showed that the influence of land-use change on the total discharge of the Dreisam basin, particularly for increased urbanisation, was minor for the seasonal and event time scale. The changes of less than $3 \%$ were within reasonably assumed uncertainty bounds of the estimated variables. These relatively small impacts on urban runoff can be explained by the rural structure of the basin, in which doubling of the urban area results in only $5 \%$ urban land use. However, similar results were obtained in catchments with somewhat larger percentages of urban areas, for instance, by Fohrer et al. (2001), Lahmer et al. (2001), Klöcking and Haberlandt (2002) and Niehoff et al. (2002).

More significant land-use change impacts could be observed if the compositions of different runoff components during the seasonal and event time scales were analysed. This can only be done with a process-based model. Of course, drastic increases in urban runoff in the urbanisation scenario might cause local flooding problems, for instance near the inflow of an urban drainage system or in a larger urbanised sub-basin. Water quality impacts are also likely but have not been addressed in this study. The analysis of the potentially natural conditions showed significantly lower flood peaks, particularly for short and convective events. In addition, reduced groundwater recharge and groundwater discharge were simulated in the porous aquifer of the Zartener Becken, which is used to supply drinking water to the city of Freiburg. Thus, the vulnerability of this groundwater resource should be considered in management plans, for instance in planned afforestation.

The results of this study demonstrate that the impact of land-use change on hydrological regimes cannot be generalised. It is important to differentiate between different temporal and spatial time scales. If floods are a concern, then the type and magnitude of the floods must be considered. The examination of floods generated by rain 
events of different recurrence intervals demonstrated the varying impacts of different rainfall durations. However, the effects of different temporal rainfall intensity distributions are greater than those of the land-use change scenarios investigated in the Dreisam basin. This illustrates the uncertainty that is introduced in the runoff prediction by assuming only one (sometimes arbitrarily chosen) distribution. A careful analysis of the temporal distribution of rainfall intensities for historical events of similar size is essential.

Other sources of uncertainty are linked with the simulations, even when a well-designed process-based model is applied. This is because the changes to processes during land-use changes are complex and not completely understood (e.g. McCulloch and Robinson, 1993; DVWK, 1999; Niehoff, 2001). Uncertainties are additionally caused by (i) input data and the regionalisation of point measurements to catchment scale (Blöschl and Grayson, 2000), (ii) model parameters that are not measurable in the field but determined by calibration (equifinality problem - Beven and Binley, 1992), (iii) simplifications inherent in the model structure that is defined by limited understanding of basin functioning (Grayson et al., 1992), and (iv) mathematical descriptions of various processes (Beven, 2001). For simulation of future floods of different magnitudes, the extrapolation problem is also introduced (Bergström, 1991; Beven, 2001). So far, no generally accepted uncertainty estimation method exists (Sivapalan et al., 2003) but for simpler models rigorous uncertainty estimation can be made (e.g. Freer et al., 1996). However, for the complex process-based model used in this study, such an approach cannot be transferred directly. Developing methods to provide a solution is a challenge for future research.

For the given data base and knowledge about the dominant hydrological processes at the Dreisam basin, the authors feel that the impact of land-use change scenarios is modelled nearly as well as possible given current knowledge and data limitations. To take a major step forward and to be able to estimate the impacts more accurately and reliably, more spatially and temporally distributed data, and better understanding of governing processes under changed circumstances are required; channel processes, runoff generation processes on the hill slopes must also be studied. Consequently, data collection in catchments exposed to landuse change is essential. Future investigations should focus on multi-scale and multi-technical field experiments (i.e. applying remote sensing, tracer and soil physical techniques simultaneously), and in parallel with the development of conceptualisation and parameterisation schemes to translate the experimental results into model space.

\section{Acknowledgements}

The authors thank the German research foundation (Deutsche Forschungsgemeinschaft, DFG, Bonn, Germany) for financial support, grant no. Le 698/12-1, and the Landesstiftung Baden-Württemberg for a post-doc grant (Eliteförderung für Postdoktoranden, Baden-Württemberg). Many thanks to Uta Fritsch (Potsdam Institute for Climate Impact Research, D-14412 Potsdam, Germany) for help during the application of the LUCK model. The English was corrected by Kendall Watkins. Thanks are also due to the working group of Prof. Goßmann (Institute of Physical Geography, University of Freiburg), the German Weather Service (DWD, Offenbach) and the federal environment agency (UBA, Berlin) for providing the meteorological data, and to the agency for environmental protection BadenWürttemberg (LfU Baden-Württemberg, Karlsruhe) for the runoff data.

\section{References}

Abbott, M.B. and Refsgaard, J.C., 1996. Distributed hydrological modelling. Water Science and Technology Library, Vol. 22, Kluwer, Dordrecht, The Netherlands.

Armbruster, V., 2001. Berechnung der Grundwasserneubildung in Baden-Württemberg (Estimation of groundwater recharge in Baden-Württemberg, in German). Freiburger Schriften zur Hydrologie, Band 14, University of Freiburg, Institute of Hydrology, Germany.

Bartels, H., 1997. Starkniederschlagshöhen für Deutschland (KOSTRA-Atlas). Deutscher Wetterdienst, Offenbach, Germany..

Bergström, S., 1991. Principles and confidence in hydrological modelling. Nordic Hydrol., 22, 123-136.

Bergström, S., 1992. The HBV model - its structure and applications. SMHI, RH, 4, Norrköping, Sweden.

Beven, K.J., 2001. Rainfall-Runoff Modelling. The Primer. Wiley, Chichester, UK. 360pp.

Beven, K.J. and Binley, A., 1992. The future of distributed models: model calibration and uncertainty prediction. Hydrol. Process., 6, 279-298.

Blöschl, G. and Grayson, R., 2000. Spatial Observations and Interpolation. In: Spatial Patterns in Catchment Hydrology, R. Grayson and G. Blöschl (Eds.) Cambridge University Press, Cambridge, UK, 51-81.

Braden, H., 1985. Ein Energiehaushalts- und Verdunstungsmodell für Wasser- und Stoffhaushaltsuntersuchungen landwirtschaftlich genutzter Einzugsgebiete. Mitteilungen Deutsche Bodenkundliche Gesellschaft, 422, 294-299.

Bremicker, M., 2000. Das Wasserhaushaltsmodell LARSIM Modellgrundlagen und Anwendungsbeispiele. Freiburger Schriften zur Hydrologie, Band 11, Institut für Hydrologie der Universität Freiburg i.Br.Germany.

Chow, V.T., Maidment, D.R. and Mays, L.W., 1988. Applied Hydrology. McGraw-Hill, New York, USA..

Dam, J.C. van, 2000. Field-scale water flow and solute transport: SWAP model concepts, parameter estimation and case studies. Dissertation. Wageningen Institute for Environment and Climate Research, Wageningen Universiteit, The Netherlands.

Dingman, S.L., 2002. Physical hydrology. Second edition, Prentice-Hall, Inc., USA. 
DVWK (Deutscher Verband für Wasserwirtschaft und Kulturbau e.V.), 1984. Arbeitsanleitung zur Anwendung von NiederschlagAbfluß-Modellen in kleinen Einzugsgebieten, Teil II: Synthese. Regeln zur Wasserwirtschaft, 113, Paul Parey, Hamburg, Germany.

DVWK (Deutscher Verband für Wasserwirtschaft und Kulturbau e.V.), 1996. Ermittlung der Verdunstung von Land- und Wasserflächen. Merkblätter zur Wasserwirtschaft, 238. Bonn, Germany.

DVWK, 1999. Einflüsse land- und forstwirtschaftlicher Maßnahmen auf den Hochwasserabfluß - Wissensstand, Skalenprobleme, Modellansätze. Mitteilungen 7/1999, Deutscher Verband für Wasserwirtschaft und Kulturbau e.V., Bonn, Germany.

Eisele, M., Kiese, R., Krämer, A. and Leibundgut, C., 2001. Application of a catchment water quality model for assessment and prediction of nitrogen budgets. Phys. Chem. Earth (B), 26, 547-551.

Fohrer, N., Haverkamp, S., Eckhardt, K. and Frede, H.-G., 2001. Hydrologic response to land use changes on the catchment scale. Phys. Chem. Earth (B), 26, 577-582.

Freer, J., Beven, K.J. and Ambroise, B., 1996. Bayesian estimation of uncertainty in runoff prediction and the value of data: An application of the GLUE approach. Water Resour. Res., 32, 2161-2173.

Fritsch, U., 2002. Entwicklung für Landnutzungsszenarien für landschaftsökologische Fragestellungen. Dissertation, Universität Potsdam, Germany.

Fuchs, P., Müller-Westermeier, G. and Schmidt, A., 2001. Mittlere jährliche Niederschlagshöhe (ohne Korrektur). Hydrologischer Atlas von Deutschland, Blatt 2.2, Herausgeber: Bundesministerium für Umwelt, Naturschutz und Reaktorsicherheit, Bonn/Berlin (2. Lieferung).Germany.

Güntner, A., Uhlenbrook, S., Seibert, J. and Leibundgut, C., 1999. Multi-criterial validation of TOPMODEL in a mountainous catchment. Hydrol. Process., 13, 1603-1620.

Grayson, R.B., Moore, I.D. and McMahon, T.A., 1992. Physically based hydrologic modeling, 2. Is the concept realistic? Water Resour. Res., 26, 2659-2666.

Hoyningen-Huene, J. von, 1983. Einfluß der Landnutzung auf den Gebietswasserhaushalt. Schriftenreihe des Deutschen Verbandes für Wasserwirtschaft und Kulturbau, 57, Paul Parey, Hamburg, Germany.

Karssenberg, D., Burrough, P.A., Sluiter, R. and de Jong, K., 2001. The PCRaster software and course materials for teaching numerical modelling in the environmental sciences. Trans. GIS, $\mathbf{5}, 99-110$

Kleinhans, A., 2000. Anwendung des Wasserhaushaltsmodells WaSiM-ETH im Dreisam-Einzugsgebiet. Diplomarbeit, Institut für Hydrologie, Universität Freiburg i.Br., Germany.

Klemes, V., 1986. Operational testing of hydrological simulation models. Hydrolog. Sci. J., 31, 13-24.

Klöcking, B. and Haberlandt, U., 2002. Impact of land use change on water dynamics - a case study in temperate meso and macroscale river basins. Phys. Chem. Earth (B), 27, 619-629.

Lahmer, W., Pfützner, B. and Becker, A., 2001. Assessment of land use and climate change impacts on the mesoscale. Phys. Chem. Earth (B), 26, 565-575.

LfU (Landesanstalt für Umweltschutz), 1992. Potentielle natürliche Vegetation und naturräumliche Einheiten. Untersuchungen zur Landschaftsplanung, Band 21.

McCulloch, J.S.G. and Robinson, M., 1993. History of forest hydrology. J. Hydrol., 150: 189-216.
Mehlhorn, J., 1999. Tracerhydrologische Ansätze in der Niederschlags-Abfluss-Modellierung. PhD Thesis, Freiburger Schriften zur Hydrologie, Band 9, University of Freiburg, Freiburg, Germany.

Menzel, L., 1997. Modellierung der Evapotranspiration im System Boden-Pflanze-Atmosphäre. $\mathrm{PhD}$ thesis, Züricher Geographische Hefte, 67, ETH Zürich, Zürich, Switzerland.

Nash, J.E. and Sutcliffe, J.V., 1970. River flow forecasting through conceptual models, Part I - a discussion of principles. J. Hydrol., 10, 282-290.

Niehoff, D., 2002. Modellierung des Einflusses der Landnutzung auf die Hochwasserentstehung in der Mesoskala. Brandenburgische Umweltberichte, 11, Schriftenreihe der Mathematisch-Naturwissenschaftlichen Fakultät der Universität Potsdam, Germany.

Niehoff, D., Fritsch, U. and Bronstert, A., 2002. Land-use impacts on storm-runoff generation: scenarios of land-use change and simulation of hydrological response in a meso-scale catchment in SW-Germany. J. Hydrol., 267, 80-93.

POTRAD, 2003. Potential Radiation Equator model, Version 5 date: 2003-04-22),, http://www.geo.vu.nl/ damo/potrad/ potrad.htm

Ries, J., 1992. Exkursion zu den skitouristisch bedingten Landschaftsschäden am Schauinsland. In: Schwarzwald und Oberrheintiefland, Freiburger Geographische Hefte, R.Mäckel and B. Metz (Eds.) Heft 36, Universität Freiburg, Institut für Physische Geographie, Freiburg, Germany.

Schulla, J., 1997. Hydrologische Modellierung von Flussgebieten zur Abschätzung der Folgen von Klimaänderungen. Züricher Geographische Schriften, Heft 69, Geographsiches Institut ETH, Zürich, Switzerland.

Shuttleworth, W.J., 1993. Evapotranspiration. In: Handbook of Hydrology, D.R.Maidment (Ed.), McGraw-Hill, New York, USA.

Sivapalan, M., Takeuchi, K., Franks, S.W., Gupta, V.K., Lakshmi, V., McDonnell, J.J., Mendiondo, E.M., O'Connell, P.E., Pomeroy, J.W., Schertzer, D., Uhlenbrook, S. and Zehe, E., 2003. IAHS Decade on Predictions in Ungauged Basins (PUB), 2003-2012: shaping an exciting future for the hydrological sciences. Hydrolog. Sci. J., 48, 857-880.

Tilch, N., Uhlenbrook, S., Leibundgut, Ch., 2002. Regionalisierungsverfahren zur Ausweisung von Hydrotopen in von periglazialem Hangschutt geprägten Gebieten. Grundwasser, 7, 206-216.

Trenkle, H. and von Rudloff, H.,1989. Das Klima im Schwarzwald. In: Der Schwarzwald - Beiträge zur Landeskunde, E.Liehl and W.D.Sick (Hrsg.), Konkordia GmbH, Bühl/Baden, Germany.

Uhlenbrook, S. and Leibundgut, Ch., 2002. Process-oriented catchment modelling and multiple-response validation. Hydrol. Process., 16, 423-440

Uhlenbrook, S., Seibert, J., Leibundgut, C. and Rodhe, A., 1999. Prediction uncertainty of conceptual rainfall-runoff models caused by problems to identify model parameters and structure. Hydrolog. Sci. J., 44, 279-299.

Uhlenbrook, S., Frey, M., Leibundgut, C. and Maloszewski, P., 2002. Hydrograph separations in a mesoscale mountainous basin at event and seasonal timescales. Water Resour. Res., 38, 1-14.

Uhlenbrook, S., Roser S. and Tilch, N., 2004. Hydrological process representation at the meso-scale: The potential of a distributed, conceptual catchment model. J. Hydrol. (in press).

Wegehenkel, M., 2002. Estimating of impact of land use changes using the conceptual hydrological model THESEUS - a case study. Phys. Chem. Earth (B), 27, 631-640. 